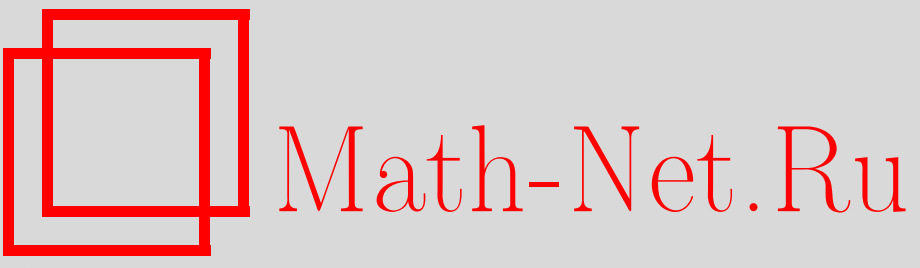

S. N. Popova, In memory of Evgeny Leonidovich Tonkov (1940-2014), Izv. IMI $U d G U, 2020$, Volume 56, 3-4

DOI: https://doi.org/10.35634/2226-3594-2020-56-00

Use of the all-Russian mathematical portal Math-Net.Ru implies that you have read and agreed to these terms of use

http://www.mathnet.ru/eng/agreement

Download details:

IP: 3.80 .253 .173

April 26, 2023, 15:46:01 


\section{Предисловие к выпуску}

Этот выпуск журнала «Известия Института математики и информатики Удмуртского государственного университета» посвящен памяти Евгения Леонидовича Тонкова (19402014), основателя Ижевской математической школы по теории управления.

История создания этой школы весьма интересна и поучительна своей связью с историей развития высшего образования в Удмуртии. В 1952 году для обеспечения квалифицированными инженерными кадрами промышленности Ижевска и республики на основании Постановления Совета Министров СССР был создан Ижевский механический институт. На начальном этапе его организации был широко использован потенциал Московского высшего технического училища им. Н. Э. Баумана, которое имело опыт подготовки инженеров в Ижевске во время эвакуации в период Великой Отечественной войны. Значительную кадровую поддержку оказали и другие технические вузы Москвы. В 1954 году в Ижевский механический институт по распределению после окончания аспирантуры при Московском станко-инструментальном институте и защиты кандидатской диссертации приехал работать Николай Викторович Азбелев, выпускник Московского авиационного института. Он возглавил кафедру высшей математики Ижевского механического института и, по сути дела, всю математическую науку Удмуртии. Н. В. Азбелев создал Ижевский городской математический семинар, в работе которого принимали участие молодые ученые, студенты и аспиранты Ижевского механического института и Удмуртского государственного педагогического института (УГПИ). Одним из участников этого семинара был Евгений Леонидович Тонков, в 1963 году окончивший Ижевский механический институт по специальности «Счетнорешающие приборы и устройства» и поступивший в аспирантуру к Н. В. Азбелеву.

В 1966 году Николай Викторович уехал из Ижевска в Тамбов, где возглавил кафедру высшей математики Тамбовского института химического машиностроения. Вместе с учителем Ижевск покинула часть его учеников, среди которых был и Е. Л. Тонков. После отъезда «костяка» работа Ижевского математического семинара не прекратилась, но научного энтузиазма создателя ему явно не хватало.

В 1971 году на базе УГПИ был создан Удмуртский государственный университет, первый ректор которого, Борис Николаевич Шульга, всеми силами и средствами пытался привлечь к работе в университете ученых со всей страны. На предложение Б. Н. Шульги откликнулось немало перспективных математиков, в числе которых был и Е. Л. Тонков, к тому времени уже кандидат наук. В 1975 году Евгений Леонидович вернулся в Ижевск, где возглавил кафедру математического анализа Удмуртского государственного университета. Его приезд способствовал и оживлению работы математического семинара, которым он стал теперь руководить. Обновленный семинар был перенесен в университет и получил название «Ижевский городской семинар по дифференциальным уравнениям и математической теории управления». Именно он стал основой для создания новой для Удмуртии научной школы.

Почти 40 лет Евгений Леонидович преподавал в Удмуртском университете. Его лекции и выступления на семинаре всегда привлекали талантливую молодежь и открывали ей путь в настоящую науку. Профессор Тонков воспитал много учеников (более 15 из них стали кандидатами и 3 - докторами наук), которым он уделял огромное внимание и с которыми щедро делился научными идеями.

Тематика работы Ижевского семинара во многом определялась работами руководителя и его многочисленными оригинальными результатами. Яркой чертой плодотворной научной деятельности Евгения Леонидовича было то, что он использовал для решения задач 
математической теории управления методы и подходы общей теории динамических систем и дифференциальных уравнений, что позволило ему получить совершенно новые результаты. Например, Е. Л. Тонков первым стал использовать динамическую систему сдвигов при исследовании линейных нестационарных систем управления, определенных на всей числовой прямой, что привело к развитию таких понятий в математической теории управления, как равномерная полная управляемость, равномерная локальная и глобальная управляемость, равномерная стабилизируемость. Ему удалось доказать весьма интересные утверждения о вероятностных характеристиках множества глобально управляемых систем, привести необходимые и достаточные условия равномерной локальной управляемости в терминах омега-предельных точек, исследовать вопрос об управляемости почти периодических и рекуррентных систем.

Е.Л. Тонков ввел понятие равномерной колеблемости однородной системы дифференциальных уравнений относительно конуса, получил целый ряд результатов в теории колеблемости. Введенное им понятие неосцилляции однородной системы дифференциальных уравнений относительно гиперплоскости позволило доказать новые утверждения о структуре множества управляемости линейной нестационарной системы, оценить число переключений управления, оптимального в смысле быстродействия (этот результат обобщает теорему А. А. Фельдбаума о числе переключений для стационарных систем), и рассмотреть задачу регулярного синтеза.

Для линейных систем управления с наблюдателем Евгений Леонидович ввел понятие равномерной согласованности. Распространив на равномерно согласованные системы метод поворотов В. М. Миллионщикова, Е. Л. Тонков доказал ряд теорем о локальной управляемости показателей Ляпунова.

Для задачи оптимального управления периодическими процессами Е. Л. Тонковым были получены необходимые условия оптимальности процесса, указаны достаточные условия невырожденности такого процесса, приведены достаточные условия эффективности расширения стационарных управлений до периодических в задаче оптимального управления периодическими движениями.

Сказанное далеко не исчерпывает весь спектр научных результатов Е. Л. Тонкова, который был автором почти 150 научных работ. Если же к ним добавить многочисленные работы его учеников, появлению которых он способствовал идеей, советом, подсказкой или прямым участием - их будет трудно сосчитать, и придется лишь удивляться неистощимой работоспособности и творческой изобретательности, которая всегда была присуща Евгению Леонидовичу.

В 2014 году Евгения Леонидовича не стало. Но он заложил прочный фундамент развития математики и математического образования в Удмуртии. Его ученики работают в вузах и на промышленных предприятиях республики и за ее пределами. В 2020 году в Институте математики, информационных технологий и физики Удмуртского государственного университета была открыта научная лаборатория математической теории управления, которой руководит В.А. Зайцев, ученик Евгения Леонидовича. Сегодня созданные по инициативе профессора Тонкова журналы «Вестник Удмуртского университета. Математика. Механика. Компьютерные науки» и «Известия Института математики и информатики Удмуртского государственного университета» входят в ведущие наукометрические базы данных Scopus и Web of Science. Есть все основания полагать, что Ижевская школа по математической теории управления, организованная Е. Л. Тонковым, будет успешно развиваться.

С. Н. Попова, зав. кафедрой дифференциальных уравнений УдГУ 